\title{
DREDGING WORKS MONITORING IN THE PORT OF CIVITAVECCHIA, ROME, ITALY: SEDIMENTOLOGICAL AND GEOCHEMICAL INVESTIGATIONS
}

\author{
DANIELE PIAZZOLLA ${ }^{1}$, SERGIO SCANU ${ }^{1}$, SIMONE BONAMANO ${ }^{1}$, \\ FRANCESCO PALADINI DE MENDOZA ${ }^{1}$, RICCARDO MARTELLUCCI ${ }^{1}$ \& GIUSEPPE ZAPPALA ${ }^{1,2}$ \\ ${ }^{1}$ Laboratory of Experimental Oceanology and Marine Ecology, Tuscia University, Civitavecchia (RM), Italy \\ ${ }^{2}$ Istituto per l'Ambiente Marino Costiero (IAMC), National Research Council, Messina, Italy
}

\begin{abstract}
Since its creation in 2001, the Laboratory of Experimental Oceanology and Marine Ecology (DEB) of Tuscia University devoted a significant part of its studies to the characterization and assessment of the coastal marine environment near Civitavecchia (central Tyrrhenian Sea, Italy), and to the influence of climatic events, as well as anthropic activities on marine environment. The coastal area of Civitavecchia is characterized by multiple uses (e.g. industrial, commercial, touristic, ecological) which result in a complex series of effects on the marine ecosystem. Civitavecchia also hosts one of the most important European ports, where several expansion works over recent times have influenced the sedimentological, geochemical and ecological characteristics (e.g., benthic biocenoses and Posidonia oceanica) of the area. Extensive dredging works in the Civitavecchia harbour were performed between November 2012 and January 2013 to build new piers and docks. The potential impact of the dredging works was assessed through an extended environmental monitoring program which was performed before and after the dredging activities. In detail, during the monitoring activities, the chemical and physical characterization of the water column, marine sediments and the assessment of the possible impact of dredging activities on the benthic ecosystem were carried out. This paper reports the results of the monitoring activities of water and sediments carried out in the harbour area and in the nearby environment. The increase of sediment fine fraction and the enrichment of trace metals in the offshore station could have been induced by dredging activities. Previous studies report the assessment of the environmental conditions before and after the dredging operations where significant variations in the composition of the benthic biocenosis and the effects on Posidonia oceanica meadows were found.
\end{abstract}

Keywords: dredging, sediments, environmental monitoring.

\section{INTRODUCTION}

The Port of Civitavecchia, founded by Emperor Trajan, as the Port of Rome, represented the cornerstone of exchange and contact among the people of ancient "Mare Nostrum" for many centuries. Thanks to the new Port Regulating Plan (PRP), the Port of Civitavecchia has increased its commercial traffic, reaching a total of two million tons of bulk goods. The Interministerial Committee for Economic Planning (CIPE) with decisions N. 140 (of 21st December 2007) and N. 2 (of 25st January 2008), together with advice from the Italian Ministry of Infrastructures and Transports, approved the final project for the "strengthening of Civitavecchia harbour hub - first parcel functional interventions: Cristoforo Colombo embankment extension, ferries and services docks realization". The Italian Ministry for the Environment, Land and Sea approved the final project of maritime works granting E.I.A. n.2935 of 22.12.1997 (the Italian Environmental Impact Assessment) and prescribed some environmental compensation activities in order to control and prevent the potential impact of the dredging activities on the environment.

The assessment plan included a series of in situ surveys and activities, aimed at characterizing marine water, sediments and contaminants, both in the harbour area and the adjacent environment. The study of sediments is fundamental because of their role in 
trapping trace metals in the marine environment [1]. At the same time, sediment resuspension caused by dredging activities results in the dispersion of particulate matter in the adjacent marine environment, both in sediment and water [2]. Furthermore, the impacts of dredging on the ecological and natural resources of a region can be various and difficult to predict [3]-[7].

Dispersion by dredging is dependent upon the characteristics of the dredged sediments and upon the marine weather conditions during the dredging activities. Dredging can lead to an increase of contaminants in the water, primarily due to their moving and transition from the particulate to the dissolved state [2], [8]-[10]. This study analyses the potential impacts of dredging activities on the marine environment surrounding the Civitavecchia harbour area.

\section{MATERIALS AND METHODS}

\subsection{The study area}

The Civitavecchia harbour is a part of the physiographic unit that extends from Capo Linaro to Monte Argentario in northern Latium (Italy). The two extremes of the physiographic unit are characterized by terraces and mountain reliefs. More in details, terraces are present from the southern area of Civitavecchia to the northern area of the Mignone river mouth while reliefs are present in the northern end of the physiographic unit related to the area of Monte Argentario, respectively. The remaining parts are dominated by alluvional plains. The morphology of the emerged coastal portion is intimately related to that of the seabed. The bathymetry shows a very articulate trend with the presence of rocky bottom and reliefs. The outcrops mainly consist of cemented fossiliferous calcarenite (middle-upper Pleistocene bench) and arenaceous-marly flysch (Upper Cretaceous sandstone), which are also present in the mainland [11]. The offshore limit of these rocky structures can be found at a depth of $25 \mathrm{~m}$, with the presence of discontinuities in correspondence to the incisions created by the river courses. From the northern part of Civitavecchia up to Cape Linaro, the shoreline assumes a high coast morphology and the seabed slope increases sharply. This morphology reaches up to $30 \mathrm{~m}$, where there is a change towards progressive gradients with lower slopes.

The studied coastal area is characterized by the presence of Fiora, Marta and Mignone river basins [12], [13]. These basins provide the coastal terrigenous inputs generated by the washout of the Plio-Quaternary volcanic outcrops of the Vulsini, Sabatini and Vicani mountains and of the Cerite-Tolfetano complex [14]. The sedimentary processes of the considered physiographic unit are influenced by continental terrigenous inputs resulting from the afferent basins and by the presence of large areas covered by bioconstructions and $P$. oceanica meadows. The bioconstructions and the Posidonia meadows are particularly important for coastal transport since they generate areas of hydrodynamic calm that favour fine sediments storage. From a mineralogical point of view, the heavy and light minerals distribution indicates the existence of a littoral sediment drift directed towards North West, which is in agreement with the main direction of currents and greater intensity winds [15]. The predominant material migration toward North West is also confirmed by the arsenic and mercury concentrations in the marine sediment between the Mignone river and Monte Argentario [16]-[19].

The Civitavecchia harbour is located about 31 miles north of Rome, in the Central Tyrrhenian Sea, encompassing a coastal area of about 5 miles. The embankment extension design is oriented northwards (Fig. 1). During the first project phase, the dredging of the 


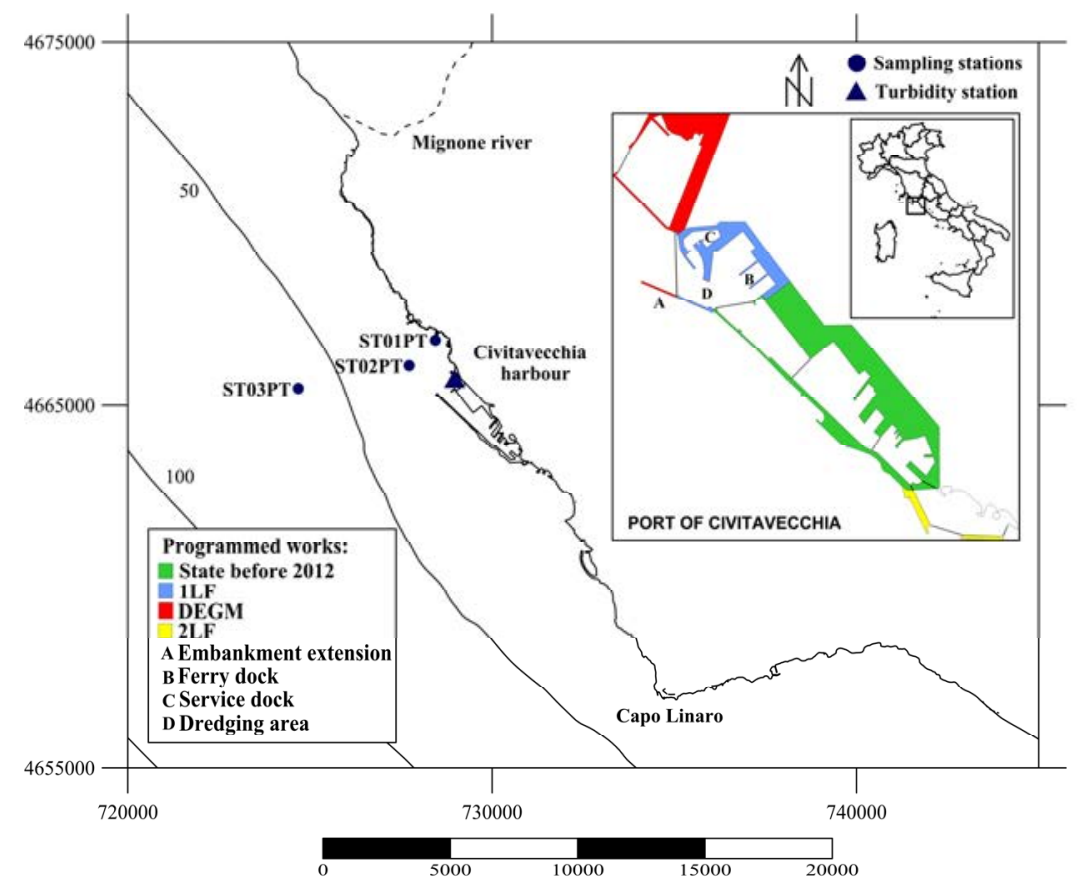

Figure 1: Location of the sediment sampling points, turbidity fixed station, the port configuration before 2012 and the new projects that will be realized in the following order: first lot of strategic works (1LF), dock energetic great masses (DEGM) and second lot of strategic works (2LF).

channel to access the port of Civitavecchia was made deepening the seabed up to a depth of $17 \mathrm{~m}$ over an area of approximately $31,000 \mathrm{~m}^{2}$, while for the ferry dock area the seabed reaches a depth of $10 \mathrm{~m}$ over an area of approximately $123,650 \mathrm{~m}^{2}$ and $15 \mathrm{~m}$ over an area of approximately $51,900 \mathrm{~m}^{2}$. The total volume of this dredging amounts to $918,000 \mathrm{~m}^{3}$. The dredging activities were carried out between 1st November 2012 and 31st January 2013.

The LOSEM (Laboratory of Experimental Oceanology and Marine Ecology) developed the C-CEMS (Civitavecchia Coastal Environment Monitoring System) that allows to analyse the potential impacts of the anthropogenic sources in marine environment of Civitavecchia coastal zone [20]. In detail, many studies concerning the bacterial dispersion in bathing areas [21]-[24], the effects of dredging activities on P. oceanica meadows and soft bottom benthic community [25] and water quality within Civitavecchia port [26], [27] have been carried out. Moreover, new low cost environmental monitoring technologies have been developed by the LOSEM and tested in the study area [28].

Fig. 1 shows the port configuration before 2012, the area of the dredging carried out between the 1st November 2012 and the 31st January 2013 and the related developments planned in the final realization of the port structure.

\subsection{Collection of sediment samples}

Surveys were carried out before (11th October 2012) and after the dredging activities (10th January 2013 and 19th February 2013). Samplings were conducted at three stations located 
outside the harbour (ST01PT, ST02PT, ST03PT) (Fig. 1) where surface sediment samples were collected using a Van Veen grab.

To avoid contamination from sides and edges of the grab, sediments were sub-sampled from the centre of the grab and then transferred into $500 \mathrm{~g}$ polythene wide-mouth jars. To prevent deterioration during their transport to the laboratory, sediments were stored at $4{ }^{\circ} \mathrm{C}$.

\subsection{Turbidity fixed station}

Resuspension of sediments due to dredging can cause a temporary decrease in water transparency, increasing the suspended particulate material concentrations and its successive deposition [29]. A multi parametric measurement station was installed in the dredging area in order to continuously monitor the main physical, chemical and biological parameters of marine water. It hosts a series of sensors for the measurement of temperature, conductivity, $\mathrm{pH}$, dissolved oxygen, chlorophyll-a fluorescence and turbidity, managed by a a CR1000 data logger programmed to acquire data at $20 \mathrm{~min}$ intervals. The system was installed on a dock in the Civitavecchia harbour measuring at a depth of $3 \mathrm{~m}$. In this study the investigated parameter is the turbidity, measured by an OBS300 probe that is widely used to monitor sediment resuspension and suspended matter in marine water from the relative intensity of backscattered light. This instrument is widely used to monitor sediment resuspension and transport [30]. In situ calibrations were performed through measures of the content of TSS (total suspended solids) according to standard methods [31] using a messenger weight-triggered Niskin bottle for water sampling.

\subsection{Laboratory analysis}

First, to obtain information relating to the abundances of the various sediment fractions, grain size analysis performed through wet sieving of sediment samples previously treated with $16 \%$ solution of $\mathrm{H}_{2} \mathrm{O}_{2}$ [32]. The pelite, sand and pebbles percentage was recorded for each sample (Table 1). Trace metals ( $\mathrm{Al}, \mathrm{As}, \mathrm{Cd}, \mathrm{Cr}, \mathrm{Ni}, \mathrm{Pb}, \mathrm{Cu}$ and $\mathrm{Zn}$ ) were analyzed in sediment samples using inductively coupled plasma-atomic emission spectrometry (ICPAES) according to EPA 3051A2007 and EPA 6010C2007 standard procedures. Table 1 shows the original geochemical dataset.

Table 1: Geochemical dataset under study. B and A indicate before and after dredging situation respectively. Pelite (Pel), Sand and Pebble (Peb) content are in \%. Trace metals values are in $\mathrm{mg} / \mathrm{Kg}$.

\begin{tabular}{|c|c|c|c|c|c|c|c|c|c|c|c|c|}
\hline & ST & Pel & Sand & Peb & Al & As & Cd & $\mathrm{Cr}$ & $\mathbf{N i}$ & $\mathbf{P b}$ & $\mathrm{Cu}$ & Zn \\
\hline \multirow{3}{*}{ B } & 01PT & 46.7 & 53.3 & 0 & 8280 & 12.8 & 0.26 & 15.2 & 20.0 & 12.0 & 11.5 & 63.6 \\
\hline & 02PT & 74.7 & 25.3 & & 50620 & 19.5 & 0.95 & 38.6 & 33.7 & 38.4 & 24.3 & 110 \\
\hline & 03PT & 66.8 & 33.2 & & 70050 & 22.8 & 1.2 & 52.7 & 47.0 & 50.3 & 29.5 & 121 \\
\hline \multirow{6}{*}{ A } & 01PT & 14.4 & 81.2 & 4.4 & 3190 & 15.5 & 0.12 & 5.9 & 3.3 & 5.5 & 3.0 & 13.8 \\
\hline & 02PT & 82.01 & 17.99 & & 17520 & 1.3 & 1.0 & 74.1 & 69.3 & 50.1 & 44.1 & 165 \\
\hline & 03PT & 94.3 & 5.7 & & 13200 & 14.1 & 0.42 & 29.3 & 25.4 & 28.7 & 19.7 & 140 \\
\hline & 01PT & 3.48 & 96.52 & 0 & 5716 & 14.4 & 0.16 & 11.5 & 8.5 & 9.1 & 7.5 & 12.7 \\
\hline & 02PT & 68.12 & 31.88 & & 19638 & 4.5 & 1.2 & 72 & 63.1 & 55.7 & 45.1 & 162 \\
\hline & 03PT & 90.63 & 9.37 & & 13560 & 14.9 & 0.43 & 30.0 & 26.3 & 28.7 & 19.6 & 147 \\
\hline
\end{tabular}




\subsection{Assessment of sediment contamination}

In order to give a complete picture of the geochemical abundances and to assess the potential ecological risk and toxicity, trace metal values were compared with the SQGs (US EPA sediment quality guidelines) numerical indices effects range low (ERL) and effects range medium (ERM). These numerical values are originally determined as in [33] and later refined according to [34]. The ERL was calculated as the lower 10th percentile of "effects" concentrations and the ERM as the 50th percentile of "effects" concentrations.

\section{RESULTS}

\subsection{Sediment characteristics}

The grain size abundances obtained by the sediment samples analysis before and after the dredging activities are shown in Fig. 2. In order to define a temporal variation trend, grain size data were represented in the three sampling days per each station.
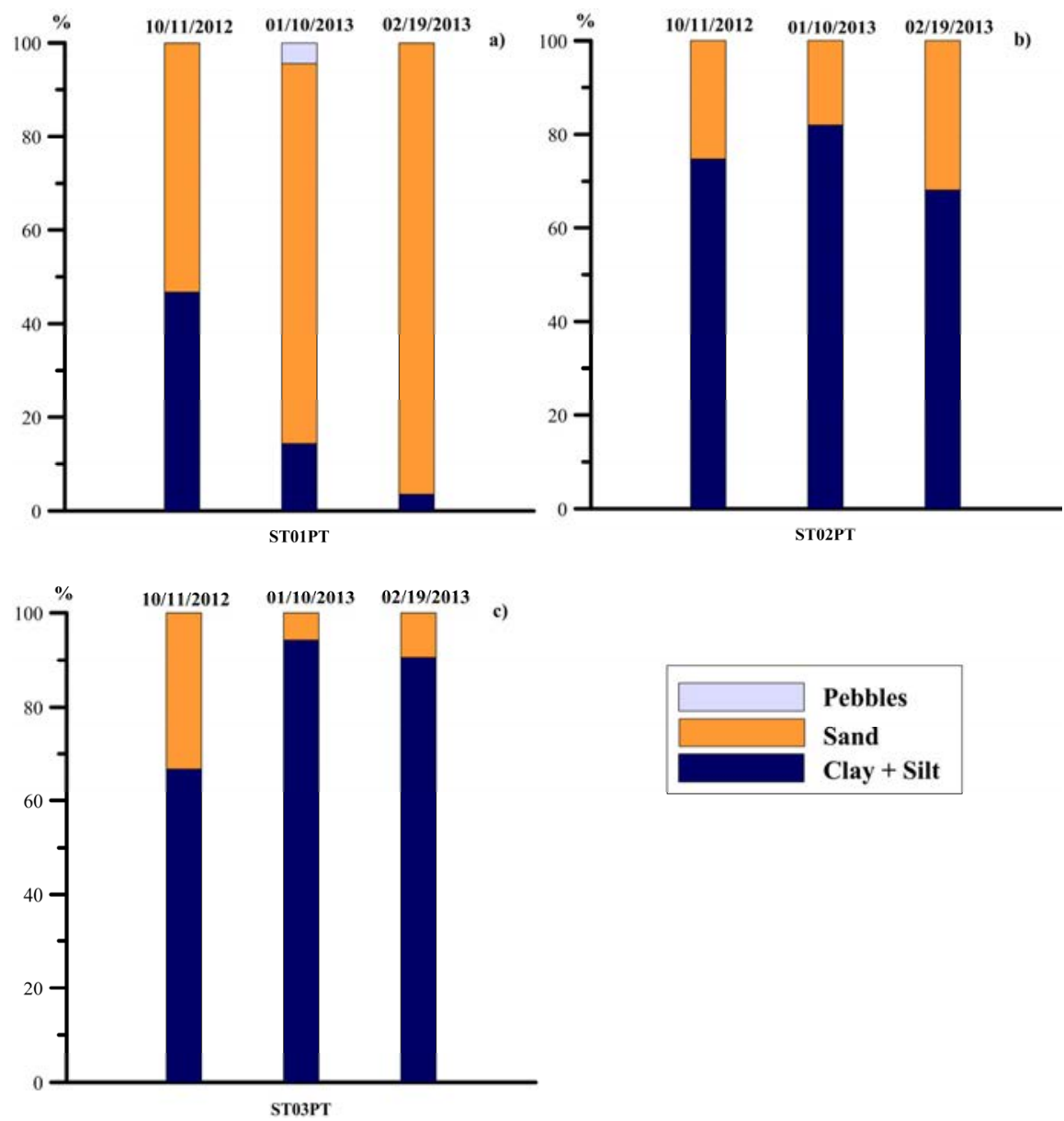

Figure 2: Grain size temporal variations during the three sampling surveys. 
The ST01PT sampling station (Fig. 2(a)) shows a strong decrease of the pelitic fraction starting from the initial conditions to the post dredging situation from 46.7 to $3.48 \%$. STO2PT (Fig. 2(b)) shows an increase in the pelitic fraction during the first sampling after the dredging activities from 74.7 to $82.01 \%$ and a significant decrement during the last sediment sampling down to $68.1 \%$. Regarding the ST03PT sampling station (Fig. 2(c)), a considerable increase in the pelitic fraction was observed during the first sampling after the dredging activities compared with the situation before the dredging activities (the percentage $<63 \mu \mathrm{m}$ has increased from 66.8 to $94.3 \%$ ), then remained stable around this value during the last sediment sample campaign (90.6\%).

\subsection{Sediments contamination}

The comparison of the trace metals abundances with the SQGs numerical indices ERM and ERL shows some variations in the contamination levels attributable to dredging operations (Table 2). The situation before the dredging works shows mostly low contamination levels. In details, As values exceeded the ERL level at all the three sampling stations; Ni valus in ST02PT exceeded the ERL level; $\mathrm{Ni}$ and $\mathrm{Pb}$ exceeded the ERL value in ST03PT.

Sediment samples collected after the dredging operations show increases in the contamination levels in ST02PT and ST03PT: As concentrations exceeded the ERL value; $\mathrm{Pb}, \mathrm{Cu}$ and $\mathrm{Zn}$ concentrations exceeded the ERL value whereas Ni concentrations exceeded the ERM value.

\subsection{Marine water turbidity}

Fig. 3 shows the temporal variations of the turbidity before and during the dredging period (between 1st July 2012 and 31st January 2013). The suspended material measured during this period shows that the concentration did not increase during the dredging activities. This is clearly visible from the TSS trends for the two periods. Fig. 3 shows that, before dredging activities, TSS varied from a minimum of $8.6 \mathrm{mg} / \mathrm{l}$ to a maximum of $15.17 \mathrm{mg} / \mathrm{l}$, while during the dredging TSS varied between $5.5 \mathrm{mg} / \mathrm{l}$ and $14.88 \mathrm{mg} / \mathrm{l}$, as reported in Fig. 3 . As expected, inside the port the turbidity normally shows higher values than the external area due to the high residence time masking the effect of dredging activities.

Table 2: Comparison of trace metals concentrations with the SQGs numerical indices ERM and ERL. B and A indicate before and after dredging situation respectively. Pelite (Pel), Sand and Pebble (Peb) content are in \%. Trace metals values are in $\mathrm{mg} / \mathrm{Kg}$. Shadowed values ecidence measurements exceeding numerical indices.

\begin{tabular}{|c|cccccccccccc|}
\cline { 2 - 13 } \multicolumn{1}{c|}{} & ST & Pel & Sand & Peb & Al & As & Cd & Cr & Ni & Pb & Cu & Zn \\
\hline \multirow{4}{*}{ B } & $01 \mathrm{PT}$ & 46.7 & 53.3 & 0 & 8280 & 12.8 & 0.26 & 15.2 & 20.0 & 12.0 & 11.5 & 63.6 \\
& $02 \mathrm{PT}$ & 74.7 & 25.3 & & 50620 & 19.5 & 0.95 & 38.6 & 33.7 & 38.4 & 24.3 & 110 \\
& $03 \mathrm{PT}$ & 66.8 & 33.2 & & 70050 & 22.8 & 1.2 & 52.7 & 47.0 & 50.3 & 29.5 & 121 \\
\hline & $01 \mathrm{PT}$ & 14.4 & 81.2 & 4.4 & 3190 & 15.5 & 0.12 & 5.9 & 3.3 & 5.5 & 3.0 & 13.8 \\
& $02 \mathrm{PT}$ & 82.01 & 17.99 & & 17520 & 1.3 & 1.0 & 74.1 & 69.3 & 50.1 & 44.1 & 165 \\
& $03 \mathrm{PT}$ & 94.3 & 5.7 & & 13200 & 14.1 & 0.42 & 29.3 & 25.4 & 28.7 & 19.7 & 140 \\
\cline { 2 - 12 } & $01 \mathrm{PT}$ & 3.48 & 96.52 & 0 & 5716 & 14.4 & 0.16 & 11.5 & 8.5 & 9.1 & 7.5 & 12.7 \\
& $02 \mathrm{PT}$ & 68.12 & 31.88 & & 19638 & 4.5 & 1.2 & 72 & 63.1 & 55.7 & 45.1 & 162 \\
& $03 \mathrm{PT}$ & 90.63 & 9.37 & & 13560 & 14.9 & 0.43 & 30.0 & 26.3 & 28.7 & 19.6 & 147 \\
\hline \multicolumn{1}{r}{} & & & & ERL & 8.2 & 1.2 & 81 & 20.9 & 46.7 & 34 & 150 \\
& & & & ERM & 70 & 9.6 & 370 & 51.6 & 218 & 270 & 410 \\
\hline
\end{tabular}


Total suspended solids at harbour fixed station

a)

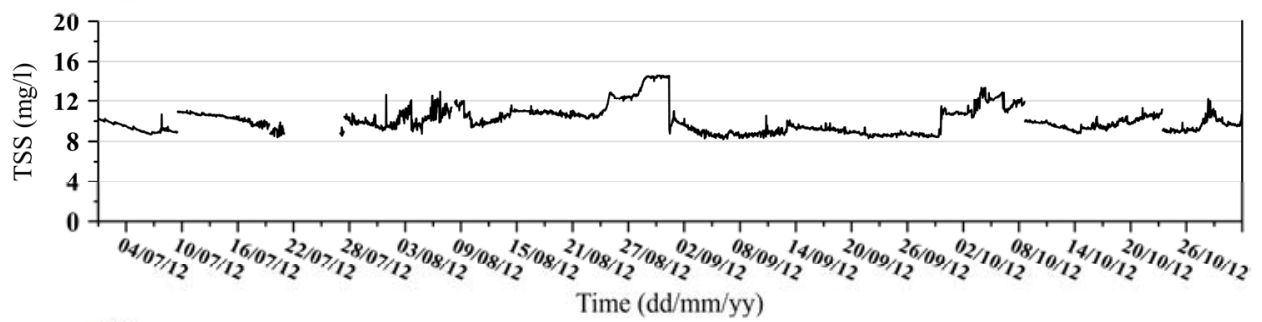

b)

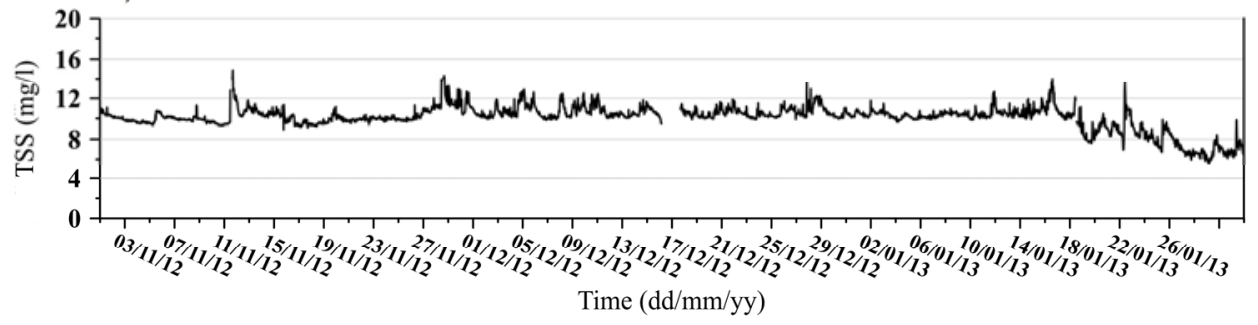

Figure 3: (a) Turbidity variations in the period before the dredging activities, between $1 \mathrm{st}$ July 2012 and 30th October 2012; (b) Turbidity variations during the dredging activities, between 1st November 2012 and 31st January 2013.

\section{DISCUSSION AND CONCLUSION}

The results derived from sedimentological investigations during the three sediment sampling campaigns show a significant temporal variation of the particle size fractions at the three sampling stations. This temporal variation was characterized by a progressive decrease in the fine particle size fraction at the sampling station closer to the coast and an increase of the same fraction at the station far from the coast.

Previous studies [3], [7], [35] showed how seabed remobilization during dredging operations leads to a resuspension of sedimentary materials. Although the coarser grain size fraction tends to precipitate almost immediately on the bottom [6], the finer fractions are redistributed along the water column and are often transported away from the dredging site [36], [37].

At ST01PT a strong decrease in the pelitic fraction is observed in the post dredging samples compared to the initial situation. Moreover, at the offshore sampling station (ST03PT) a strong increase in the pelitic fraction compared to the pre-dredging time was observed. These trends seem to confirm the distribution of particle sizes changes described in previous studies and presumably attributable to the dredging operations.

The comparison of the trace metals concentrations with the SQGs numerical indices ERL and ERM shows some variations in the contamination levels mostly in agreement with the increase of pelite fraction encountered. This process is due to the particular affinity between finer particle size fractions and trace metals that bind to their surface and subsequently follow their sedimentary fate [38]-[40].

Only the concentrations of $\mathrm{Ni}$ showed values exceeding the ERM threshold at the ST02PT station. However, in a study by Piazzolla et al. [17] the distribution of trace metals 
in marine sediments sampled in the coastal area of northern Latium in the summer of 2013 was evaluated, several months after dredging operations. Ni concentrations measured in this study showed values below the ERM threshold and a non-significant Ni pollution level. Moreover, the values of the other considered trace metals are in agreement with the present study.

Turbidity measurements are widely used as a useful tool to estimate the environmental impacts of dredging activities. The results obtained in this study confirm that the fine fraction is a good indicator of contamination in sediments and can be used as a tracer of the impact of human activities in the coastal environment.

Taking into account these results, for a better assessment of the impact of coastal works on the marine environment specific sampling plans must be prepared according to the coastal dynamics that can be studied through the joint use of numerical models and satellite observations.

\section{ACKNOWLEDGMENT}

The authors express their gratitude to the Port Authority of Civitavecchia for the financial support.

\section{REFERENCES}

[1] Calmano, W., Ahlf, W. \& Förstner, U., Sediment quality assessment: chemical and biological approaches. Sediments and Toxic Substances: Environmental Effects and Ecotoxicity, eds Calmano \& Förstner, Springer: Berlin, pp. 1-35, 1996.

[2] Van den Berg, G.A., Meijers, G.G.A, Van der Heijdt, L.M. \& Zwolsman, J.J.G., Dredging-related mobilization of trace metals: a case study in the Netherlands. Water Research, 35, pp. 1979-1986, 2001. DOI: 10.1016/S0043-1354(00)00452-8.

[3] Nayar, S., Millar, D.J., Hunt, A., Goh, B.P.L. \& Chou, L.M., Environmental effects of dredging on sediment nutrients, carbon and granulometry in a tropical estuary. Environmental monitoring and assessment, 127(1)-(3), pp. 1-13, 2007. DOI: 10.1007/s10661-006-9253-2.

[4] Windom, H.L., Environmental aspects of dredging in the coastal zone. Critical Reviews of Environmental Control, 6, pp. 91-109, 1976.

[5] Cheung, Y.H. \& Wong, M.H., Toxic effects of dredged sediments of Hong Kong coastal waters on clams. Environmental Technology, 14, pp. 1047-1055, 1993. DOI: 10.1080/09593339309385381.

[6] Lohrer, A.M. \& Wetz, J.J., Dredging-induced nutrient release from sediments to thewater column in a southeastern saltmarsh tidal creek. Marine Pollution Bulletin, 46, pp. 1156-1163, 2003. DOI: 10.1016/S0025-326X(03)00167-X.

[7] Zimmerman, L.E., Jutte, P.C. \& Van Dolah, R.F., An environmental assessment of the Charleston ocean dredged material disposal site and surrounding areas after partial completion of the Charleston Harbour deepening project. Marine Pollution Bulletin, 46, pp. 1408-1419, 2003. DOI: 10.1016/S0025-326X(03)00289-3.

[8] Forstner, U., Calmano, W., Hong, J. \& Kersten, M., Effects of redox variations on metal speciation: implications on sediment quality criteria assessment. Special Publication, The Royal Society of Chemistry: London, 154, pp. 83-102, 1994.

[9] Morse, J.W., Dynamics of trace metal interactions with authigenic sulfide minerals in anoxic sediments. Metal Contaminated Aquatic Sediments, ed. H.E. Allen, Ann Arbor Press: Ann Arbor, MI, pp. 187-199, 1995.

[10] Forstner, U. \& Calmano, W., Characterisation of dredged materials. Water Science and Technology, 38(11), pp. 149-157, 1998. DOI: 10.1016/S0273-1223(98)00650-7. 
[11] Chiocci, F.L. \& La Monica, G.B., Analisi sismostratigrafica della piattaforma continentale. Il Mare del Lazio: Elementi di oceanografia fisica e chimica, biologia e geologia marina, clima meteomarino, dinamica dei sedimenti ed apporti continentali, ed. Regione Lazio, Tip. Borgia: Roma, Italia, pp. 40-61, 1996.

[12] Scanu, S., Geocronologia $(210 \mathrm{~Pb})$ dei sedimenti recenti della piattaforma costiera del Lazio settentrionale: stima del rateo di accumulo sedimentario e distribuzione spaziale e temporale delle concentranzioni di alcuni metalli in traccia (As, $\mathrm{Hg}, \mathrm{Pb}, \mathrm{Al}$ e $\mathrm{Zn})$. $\mathrm{PhD}$ thesis, Ecological and Biological Sciences Department, Tuscia University, 2012.

[13] Scanu, S., Paladini de Mendoza, F., Piazzolla, D. \& Marcelli, M., Anthropogenic impact on river basins: temporal evolution of sediment classes and accumulation rates in the northern Tyrrhenian Sea, Italy. Oceanological and Hydrobiological Studies, 44(1), pp. 74-86, 2015. DOI: 10.1515/ohst-2015- 0000.

[14] La Monica, G.B. \& Raffi, R., Morfologia e sedimentologia della spiaggia e della piattaforma continentale interna. Il Mare del Lazio, ed. Regione Lazio, Tip. Borgia: Roma, Italia, pp. 62-105, 1996.

[15] Anselmi, B., Brondi, A., Falchi, G. \& Ferretti, O., Lineamenti granulometrici e mineralogici generali dei sedimenti fluviali e costieri del territorio italiano. Memorie Società Geologica Italiana, 19, pp. 307-314, 1978.

[16] Baldi, F. \& Bargagli, R., Mercury pollution in marine sediments near a chloralkali plant: distribution and availability of the metal. The Science of the Total Environment, 39, pp. 15-26, 1984. DOI: 10.1016/0048-9697(84)90021-4.

[17] Piazzolla, D. et al., Trace-metal enrichment and pollution in coastal sediments in the Northern Tyrrhenian Sea, Italy. Archives of Environmental Contamination and Toxicology, 69(4), pp. 470-481, 2015. DOI: 10.1007/s00244-015-0166-3.

[18] Scanu, S. et al., Concentrations of $\mathrm{As}, \mathrm{Cd}, \mathrm{Cr}, \mathrm{Ni}$, and $\mathrm{Pb}$ in the echinoid Paracentrotus lividus on the coast of Civitavecchia, Northern Tyrrhenian Sea, Italy. Regional Studies in Marine Science, 1, pp. 7-17, 2015. DOI: 10.1016/j.rsma. 2015.02.001.

[19] Scanu, S. et al., Mercury Enrichment in Sediments of the Coastal Area of Northern Latium, Italy. Bulletin of Environmental Contamination and Toxicology, 96(5), pp. 630-639, 2016. DOI: 10.1007/s00128-016-1776-9.

[20] Bonamano, S. et al., The Civitavecchia Coastal Environment Monitoring System (CCEMS): A new tool to analyse the conflicts between coastal pressures and sensitivity areas. Ocean Sciences, 12, pp. 87-100, 2016. DOI: 10.5194/os-12-87-2016.

[21] Zappalà, G., Bonamano, S., Madonia, A., Caruso, G. \& Marcelli, M., Microbiological risk assessment in a coastal marine environment through the use of mathematical models. WIT Transactions on Ecology and the Environment, vol. 164, WIT Press: Southampton and Boston, pp. 3-14, 2012.

[22] Zappalà, G. et al., Integrated marine measurements in Civitavecchia (Rome) area. WIT Transactions on Modelling and Simulations, vol. 55, WIT Press: Southampton and Boston, pp. 221-235, 2013.

[23] Bonamano, S. et al., Modeling the dispersion of viable and total Escherichia coli cells in the artificial semi-enclosed bathing area of Santa Marinella (Latium, Italy). Marine Pollution Bulletin, 95, pp. 141-154, 2015. DOI: 10.1016/j.marpolbul.2015.04.030.

[24] Zappalà, G. et al., A multi-platform approach to marine environment assessment in Civitavecchia (Rome) area. Journal of Operational Oceanography, 9, pp. 131-143, 2016. DOI: 10.1080/1755876X.2015.1119561. 
[25] Bonamano, S. et al., Mathematical models supporting the monitoring of Civitavecchia harbour (Rome). WIT Transactions on Modelling and Simulations, vol. 59, WIT Press: Southampton and Boston, pp. 443-454, 2015.

[26] Zappalà, G. et al., Assessment of environmental conditions in Civitavecchia (Rome, Italy) harbour. WIT Transactions on Ecology and Environment, vol. 182, WIT Press: Southampton and Boston, pp. 271-282, 2014.

[27] Bonamano, S. et al., Development of a Predictive Tool to Support Environmentally Sustainable Management in Port Basins. Water, 9(11), p. 898, 2017. DOI: 10.3390/w9110898.

[28] Marcelli, M., Piermattei, V., Madonia, A. \& Mainardi, U., Design and application of new low-cost instruments for marine environmental research. Sensors, 14(12), pp. 23348-23364, 2014.

[29] Erftemeijer, P.L.A. \& Lewis, R.R.R., Environmental impacts of dredging on seagrasses: A review. Marine Pollution Bulletin, 52, pp. 1553-1572, 2006. DOI: 10.1016/j.marpolbul.2006.09.006.

[30] Sutherland, T.F., Lane, P.M., Amos, C.L. \& Downing, J., The calibration of optical backscatter sensors for suspended sediment of varying darkness levels. Marine Geology, 162, pp. 587-597, 2000. DOI: 10.1016/S0025-3227(99)00080-8.

[31] Strikland, J.D.H. \& Parson, T.R., A Practical Handbook of Sea-Water Analysis, Fisheries Research Board of Canada: Ottawa, 1972.

[32] Spagnoli, F., Dinelli, E., Giordano, P., Marcaccio, M., Zaffagnini, F. \& Frascari, F., Sedimentological, biogeochemical and mineralogical facies of Northern and Central Western Adriatic Sea. Journal of Marine Systems, 139, pp. 183-203, 2014. DOI: 10.1016/j.jmarsys.2014.05.021.

[33] Long, E.R. \& Morgan, L.G., The potential for biological effects of sediment-sorbed contaminants tested in the National Status and Trends Program. NOAA Technical Memorandum NOS OMA 52, NOAA Office of Oceanography and Marine Assessment: Seattle, WA, 1990.

[34] Long, E.R., MacDonald, D.D., Smith, S.L. \& Calder, F.D., Incidence of adverse biological effects within ranges of chemical concentrations in marine and estuarine sediments. Environmental Management, 19, pp. 81-97, 1995. DOI: 10.1007/BF02472006.

[35] Oertel, G.F., Report of the hydrologic and sedimentologic study of the offshore spoil disposal area, Savannah, Georgia. Proceedings of the Eighth Dredging Seminar, Center for Dredging Studies Report No. 195, pp. 194-219, 1974.

[36] Morton, J.W., Ecological Effects of Dredging and Dredge Spoil Disposal: A Literature Review, US Fish and Wildlife Service, Technical paper 94, 1977.

[37] Amson, J.E., The Tampa Harbour Project: A major monitoring success. Marine Pollution Bulletin, 19(11), pp. 637-646, 1988.

[38] Forstner, U. \& Wittman, G.T.W., Metal Pollution in Aquatic Environment, SpringerVerlag: New York, 1983.

[39] Horowitz, A.J., A Primer on Sediment-Trace Element Chemistry, 2nd ed., Lewis Publishers: Chelsea, 1991.

[40] Ligero, R.A., Ramos-Lerate, I., Barrera, M. \& Casas-Ruiz, M., Relationships between sea-bed radionuclide activities and some sedimentological variables. Journal of Environmental Radioactivity, 57, pp. 7-19, 2001. DOI: 10.1016/S0265931X(00)00213-7. 